Наносистели, нанолатеріали, нанотехнології Nanosistemi, Nanomateriali, Nanotehnologii 2019, т. 17, № 4, сc. 689-700 (c) 2019 ІМФ (Інститут металофізики ім. Г. В. Курдюмова НАН України) Надруковано в Україні. Фотокопіювання дозволено тільки відповідно до ліцензії

PACSnumbers: 81.05.Rm, 81.05.U-, 81.16.-c, 81.40.Wx, 82.45.Yz, 82.47.Cb, 82.47.Uv

\title{
Electrochemical Properties of $\beta$-Hydroxide Nickel/Carbon Composites
}

I. M. Budzulyak ${ }^{1}$, O. M. Khemii ${ }^{1}$, O. V. Morushko ${ }^{1}$, D. I. Popovych ${ }^{2}$, Yu. Starchuk ${ }^{1}$, and L. S. Yablon ${ }^{1}$

\author{
${ }^{1}$ Vasyl Stefanyk Precarpathian National University, \\ 57 Shevchenko Str., \\ UA-76018 Ivano-Frankivsk, Ukraine \\ ${ }^{2}$ Institute for Applied Problems of Mechanics and Mathematics, N.A.S. of Ukraine, \\ $3^{b}$, Naukova Str., \\ UA-79060 Lviv, Ukraine
}

In this work, conditions and regimes for the formation and modification of $\beta-\mathrm{Ni}(\mathrm{OH})_{2} / \mathrm{C}$ nanocomposites by means of laser irradiation and ultrasound are optimized. In particular, as established, the specific capacity of the condenser-type electrochemical system formed on the base of $\beta$ $\mathrm{Ni}(\mathrm{OH})_{2} / \mathrm{C}$ nanocomposites exposed to ultrasound is of 554 and $472 \mathrm{~F} / \mathrm{g}$ at currents of $5 \mathrm{~mA}$ and $10 \mathrm{~mA}$, respectively.

У цій роботі оптимізовано умови та режими утворення і модифікації лазерним опроміненням й ультразвуком нанокомпозитів $\beta-\mathrm{Ni}(\mathrm{OH})^{2} / \mathrm{C}$. Зокрема, було встановлено, що питома потужність електрохемічної системи конденсаторного типу, сформованої на основі нанокомпозитів $\beta$ $\mathrm{Ni}(\mathrm{OH})_{2} / \mathrm{C}$, що піддаються впливу ультразвуку, становить 554 та 472 $\Phi / г$ при струмах у 5 мА та 10 мА відповідно.

В данной работе оптимизированы условия и режимы формирования и модификации лазерным облучением и ультразвуком нанокомпозитов $\beta$ $\mathrm{Ni}(\mathrm{OH})^{2} / \mathrm{C}$. В частности, было установлено, что удельная ёмкость электрохимической системы конденсаторного типа, сформированной на основе нанокомпозитов $\beta-\mathrm{Ni}(\mathrm{OH})_{2} / \mathrm{C}$, подвергнутых воздействию ультразвука, составляет 554 и 472 Ф/г при токах 5 мА и 10 мА соответственHo.

Key words: nickel hydroxide, carbon, nanocomposites, ultrasound, laser irradiation.

Ключові слова: гідроксид ніклю, вуглець, нанокомпозити, ультразвук, лазерне опромінення. 
Ключевые слова: гидроксид никеля, углерод, нанокомпозиты, ультразвук, лазерное облучение.

(Received 25 June, 2019)

\section{INTRODUCTION}

The necessity to provide high specific characteristics for electrical energy storage devices stipulates the study of the possibilities of using certain materials. Nickel hydroxide is among such materials as it has a high theoretical capacity and at the same time its charge/discharge lithium electrode potential is $\cong 3 \mathrm{~V}$. However, it is high resistor, which prevents it from being used as an electrode material for hybrid supercapacitors and lithium power supplies. The use of conductive additives namely the activated carbon modified by laser irradiation and ultrasound is one of the promising ways of solving this problem. The formation of carbon nanocomposite structures makes it possible to overcome coagulation processes, which is important in the electrodes manufacture.

\section{OBJECTS AND METHODS OF INVESTIGATION}

The study of modified nickel hydroxide electrochemical behaviour in aqueous electrolytes was carried out in a three-electrode cell. The working electrodes were formed from the investigated materials by mixing them with a conductive additive (acetylene soot) in a proportion of $75: 12 \%$ and by application of it onto the $0.49 \mathrm{~cm}^{2}$ nickel grid. A platinum electrode served as a compliment and a chlorosilver $\mathrm{Ag} / \mathrm{AgCl}$ one was used as a comparison electrode. $33 \%$ aqueous potassium hydroxide $(\mathrm{KOH})$ solution was used as an electrolyte.

The specific hybrid systems energy characteristics were determined by performing potentiodynamic and galvanostatic measurements in a two-electrode electrochemical cell (EC) using the Autolab PGSTAT/FRA-2 spectrometer at a working voltage of $0-1.5 \mathrm{~V}$ and by impedance spectroscopy obtained at an open-circuit voltage of 0 $\mathrm{V}$ in the frequency range of $10 \mathrm{MHz}$ to $100 \mathrm{kHz}$.

\section{RESULTS AND DISCUSSION}

The distinctive behaviour feature of the studied electrochemical systems is that there are two oxidation-reduction peaks responsible for pseudo-power on the pure $\mathrm{Ni}(\mathrm{OH})_{2}$ voltammogram (at the scanning rate of $1,5,10 \mathrm{mV} / \mathrm{sec}$ ) (Fig. $1, a$ ). One of the peaks is anodic (positive current value) at $0.29 \mathrm{~V}$ due to the oxidation of $\mathrm{Ni}(\mathrm{OH})_{2}$ to 

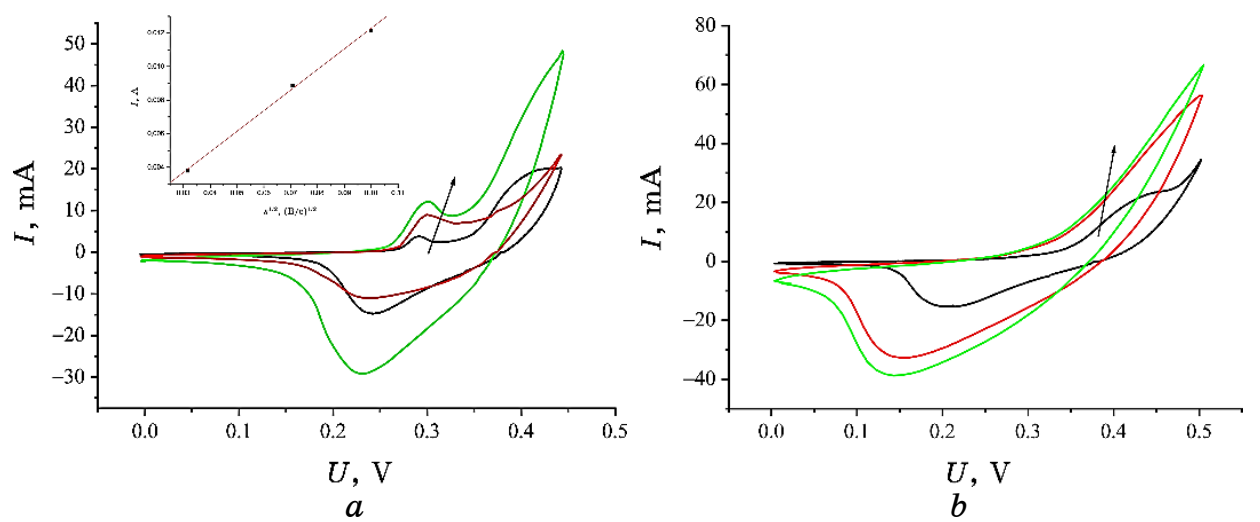

Fig. 1. Cyclic voltamperegram of $\beta-\mathrm{Ni}(\mathrm{OH})_{2}(a), \beta-\mathrm{Ni}(\mathrm{OH})_{2} / \mathrm{C}_{\text {composite }}=90: 10$ (b).

$\mathrm{NiOOH}$ corresponds to the charge while another is cathode-ray (negative current value) at $0.24 \mathrm{~V}$ is the discharge [1]. These peaks represent the fast-reversible oxidation-reduction processes taking place at the interface between $\mathrm{Ni}(\mathrm{OH})_{2}$ on the one side and the electrolyte on the other according to the equation:

$$
\mathrm{Ni}(\mathrm{OH})_{2}+\mathrm{OH}^{-} \leftrightarrow \mathrm{NiOOH}+\mathrm{H}_{2} \mathrm{O}+e^{-} .
$$

The mechanism of the discharge can be conventionally divided into three stages:

1) the recovery of nickel $\mathrm{Ni}^{3+}+e^{-} \rightarrow \mathrm{Ni}^{2+}$ ions;

2) proton entrance into the areas of crystal characterized by an increased number of proton vacancies thereby forming two energetically unstable cells in the nickel hydroxide $\left(\left[\mathrm{Ni}^{3+}(\mathrm{OH})_{2}\right]^{+}\right.$and $\left[\mathrm{Ni}^{2+} \mathrm{OOH}\right]^{-}$) crystal grid;

3) the migration of the proton vacancies from $\mathrm{Ni}^{2+}$ to $\mathrm{Ni}^{3+}$, which does not require the ion displacement, is energy-efficient and has an immediate effect; this mechanism allows to explain the long-term electrical conductivity sustention at the electrode/electrolyte boundary and in the crystal grid area.

It is possible to write the Randles-Shevchik equation for quasirotation systems, which defines the diffusion coefficient $D$ at $298 \mathrm{~K}$ as the slope of the linear part of the peak currents dependences $I_{p}$ on the square root of the scanning speed $[2,3]$ :

$$
I_{p}=2.69 \cdot 10^{5} n^{3 / 2} A D^{1 / 2} c^{0} s^{1 / 2},
$$

where $n$ is the number of electrons involved in the reaction; $A$-the surface area; $c^{0}$ - the initial concentration of the reagents. 
The ion diffusion coefficient calculated according to the equation (2) for $\beta-\mathrm{Ni}(\mathrm{OH})_{2}$ is $9.3 \cdot 10^{-10} \mathrm{sm}^{2} / \mathrm{s}$, which is sufficiently close to the value $1.7 \cdot 10^{-9} \mathrm{sm}^{2} / \mathrm{s}$ obtained by the authors of [4] using the method of accelerated impulse discharge. The peak currents' dependences on $s^{1 / 2}$ is linear (Fig. 1,a) that indicates the diffusion kinetics.

The calculated specific capacity at a scanning speed of $1 \mathrm{mV} / \mathrm{s}$ of pure $\beta-\mathrm{Ni}(\mathrm{OH})_{2}$ is $238 \mathrm{~F} / \mathrm{g}$ and of the $\beta-\mathrm{Ni}(\mathrm{OH})_{2} / \mathrm{C}$ composite of $90: 10$ is $292 \mathrm{~F} / \mathrm{g}$. It is obvious that the pseudo-power contribution is dominant in the $\beta-\mathrm{Ni}(\mathrm{OH})_{2} / \mathrm{C}$ composite. Carbon provides bigger quantity of oxidation-reduction centres by specific surface area in-
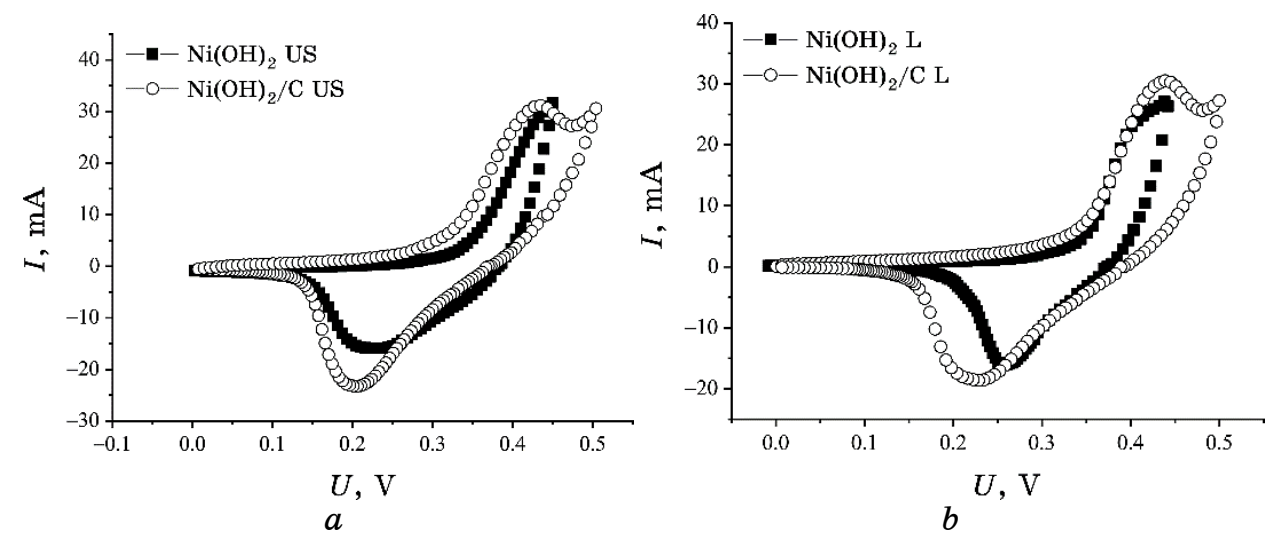

Fig. 2. Voltammograms for $\beta-\mathrm{Ni}(\mathrm{OH})_{2}$ and $\beta-\mathrm{Ni}(\mathrm{OH})_{2} / \mathrm{C}$ composite subjected to ultrasonic dispersion $(a)$ and laser irradiation $(b)$ at the scanning speed of $1 \mathrm{~mm} / \mathrm{c}$.
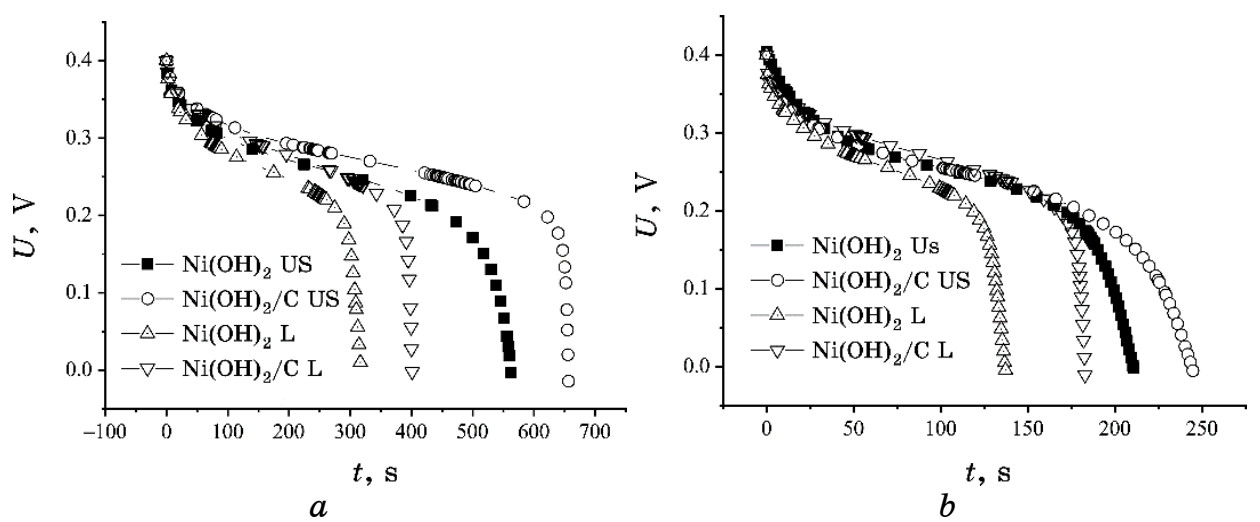

Fig. 3. Galvanostatic charging curve for $\beta-\mathrm{Ni}(\mathrm{OH})_{2}$ and $\beta-\mathrm{Ni}(\mathrm{OH})_{2} / \mathrm{C}$ composite subjected to ultrasonic dispersion $(\boldsymbol{\square}, \mathrm{O})$ and laser irradiation $(\triangle, \nabla)$, at the scanning speed of $5 \mathrm{~mA}(a)$ or $10 \mathrm{~mA}(b)$. 
TABLE 1. Specific-capacity values for composites based on $\beta-\mathrm{Ni}(\mathrm{OH})_{2}[\mathrm{~F} / \mathrm{g}]$.

\begin{tabular}{c|c|c|c|c|c|c|c|c|c|c}
\hline \multirow{3}{*}{ Material } & \multicolumn{4}{|c|}{ Ultrasonic } & \multicolumn{4}{c}{ Laser irradiation } \\
\cline { 2 - 11 } & $\begin{array}{c}\text { Scanning } \\
\text { speed, mm/s }\end{array}$ & $\begin{array}{c}\text { Current discharge, } \\
\mathrm{mV} / \mathrm{s}\end{array}$ & $\begin{array}{c}\text { Scanning } \\
\text { speed, mm/s }\end{array}$ & $\begin{array}{c}\text { Current discharge, } \\
\mathrm{mV} / \mathrm{s}\end{array}$ \\
\cline { 2 - 11 } & 1 & 5 & 10 & 5 & 10 & 1 & 5 & 10 & 5 & 10 \\
\hline $\mathrm{Ni}(\mathrm{OH})_{2}$ & 341 & 113 & 58 & 433 & 353 & 282 & 146 & 85 & 265 & 215 \\
$\mathrm{Ni}(\mathrm{OH})_{2} / \mathrm{C}$ & 411 & 279 & 140 & 554 & 472 & 326 & 236155 & 328 & 306 \\
\hline
\end{tabular}

creasing and leads to the electrode specific resistance decrease. The value of specific capacity calculated using cyclic voltammograms (Fig. 2) and galvanostatic curves materials (Fig. 3) subjected to ultrasonic dispersion and laser irradiation are presented in Table 1.

As can be seen from Table 1, both ultrasonic dispersion and laser irradiation lead to the improvement of the $\beta-\mathrm{Ni}(\mathrm{OH})_{2}$ composite specific characteristics. The subjected to ultrasonic dispersion and laser irradiation (554 and $472 \mathrm{~F} / \mathrm{g}$ at current of 5 and $10 \mathrm{~mA}$, respectively) $\mathrm{Ni}(\mathrm{OH})_{2} / \mathrm{C}$ composite has the highest specific capacity probably due to weak van der Waals bonds between nickel hydroxide layers and the formation of guest positions for ions under the action of ultrasound. Besides, the laser irradiated composite exhibits quite high specific capacity values (328 and $306 \mathrm{~F} / \mathrm{g}$ at current of 5 and $10 \mathrm{~mA}$, respectively) due to the defect increasing under the action of irradiation. The concentration of free carriers increases with the rise of defect concentration [5].

Figure 4 shows cyclic voltammograms of the studied systems and the $\lg I=f(\lg s)$ dependences (on the inserts to them). According to Eq. (2), if the dependence slope is equal to 1 , the system behaves like an ideal EC. If the angle of inclination is 0.5 , then there are diffusion processes in the system. The straight-line angle of inclination for the studied composites is $\mathbf{0 . 4 7 - 0 . 5 5}$ (the error of computation of 0.01). It testifies to the presence of diffusion processes, which are intensified due to ultrasound and laser irradiation, and therefore the ion diffusion coefficient increases. It happens due to smaller particle size and a larger specific surface area that provides the better particles contact with an electrolyte solution and promotes the rapid ions translocation, accelerates reaction and reduces the electrode polarization during the charge/discharge processes.

Impedance spectroscopy followed by Nyquist plots modelling was applied to study the electrochemical behaviour of the studied materials (Fig. 5). Selection of the elements allowed to obtain an equivalent electrical circuit (Fig. 6) consisted of connected in series resistance $R_{0}$, link $R_{1}-C P E_{1}$, and a constant phase element $C P E_{2}$. The high-frequency area is associated with the process occurring at the 


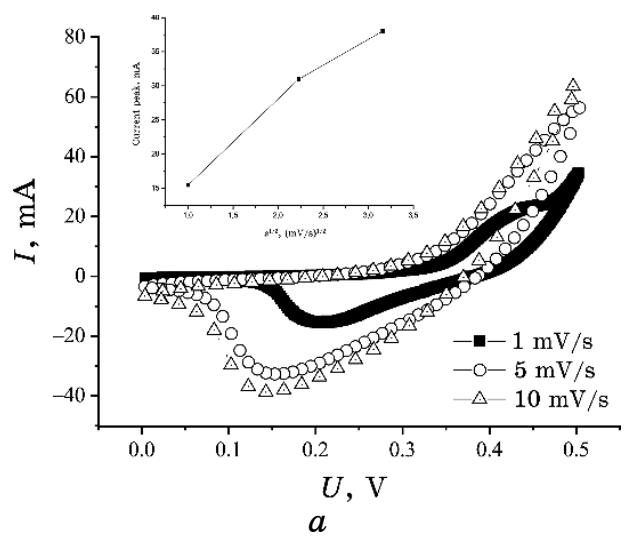

$a$
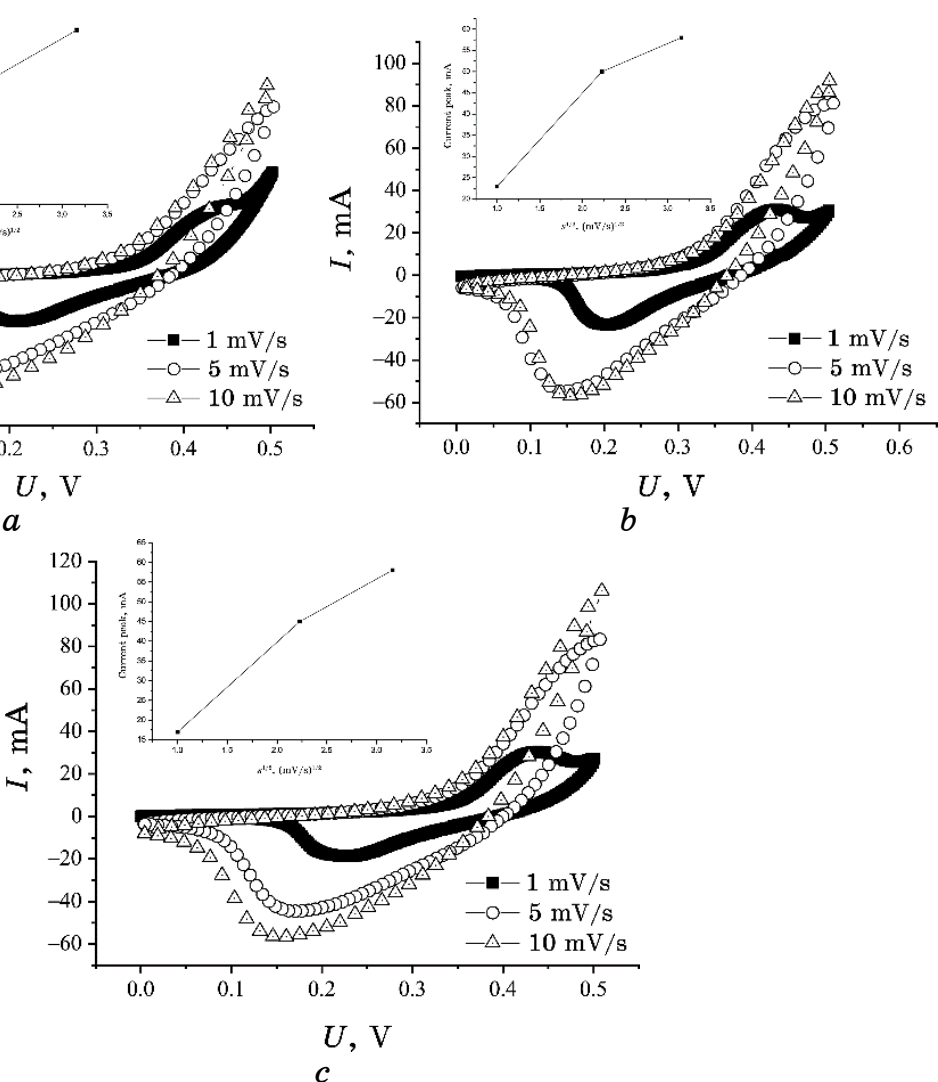

Fig. 4. Voltammograms for $\beta-\mathrm{Ni}(\mathrm{OH})_{2}$ and $\beta-\mathrm{Ni}(\mathrm{OH})_{2} / \mathrm{C}$ composite $(a)$ subjected to ultrasonic dispersion $(b)$ and laser irradiation $(c)$. Insert: peak current dependence from $s^{1 / 2}$ chart.

material/electrolyte boundary. It can be modelled in parallel to the connected element of the constant phase $C P E_{1}$, which corresponds to the double electric layer capacitance and the ion resistance $R_{1}$ arising when the charge is transferred through the electrode/electrolyte boundary. The linear Warburg impedance can be observed at lower frequencies simulated by an element $C P E_{2}$ connected in series, which is responsible for the diffusion processes of ions' translocation along the intercrystallite nickel hydroxide boundaries and carbon particles.

As can be seen from Fig. $5, a$, the $\beta-\mathrm{Ni}(\mathrm{OH})_{2}$ modification by ultrasonic dispersion and laser irradiation leads to Nyquist plots semicircle radius decrease in the high-frequency range that relates to the reduction of active material resistance, contacts and electrolyte. It can be explained by the processes occurring at the elec- 

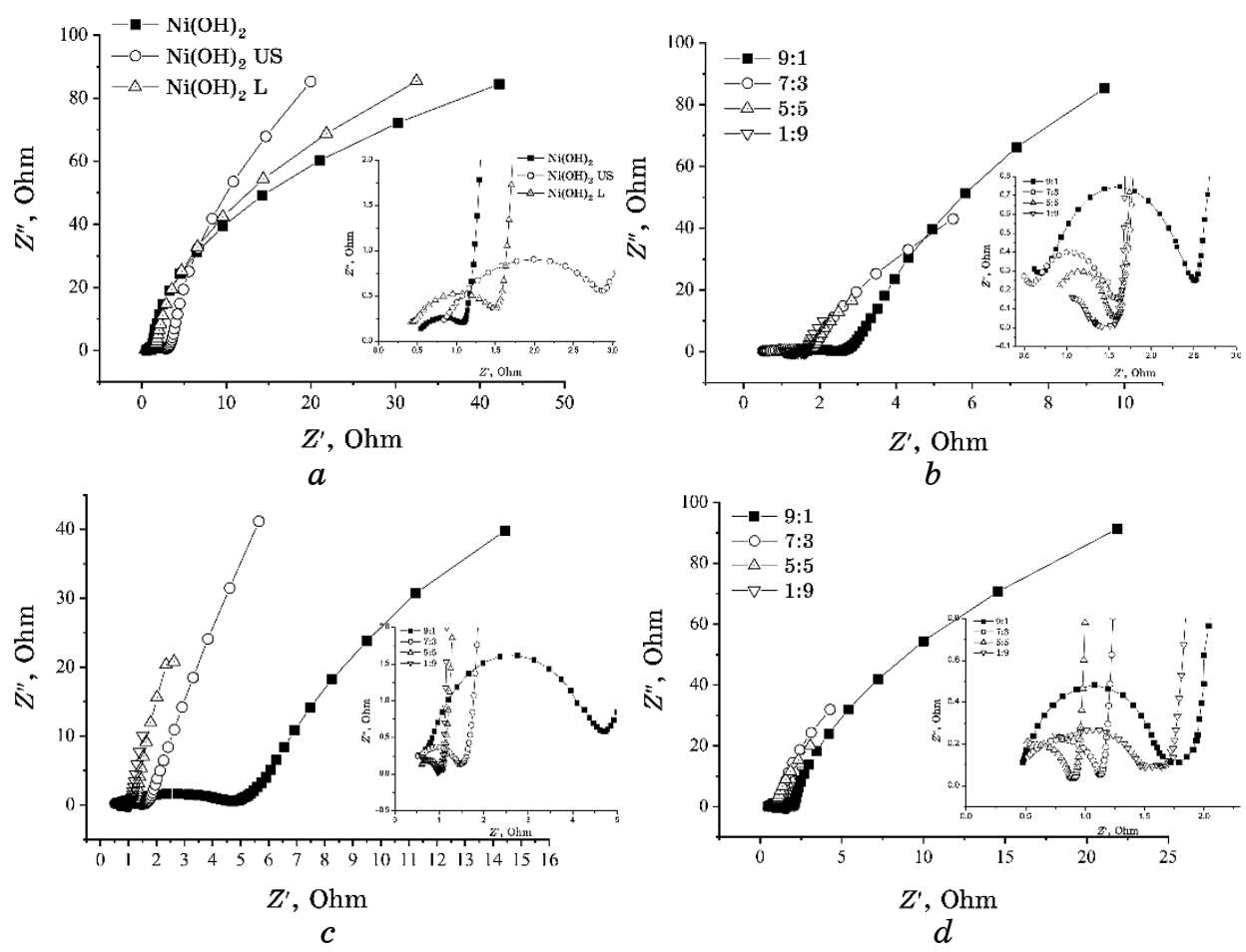

Fig. 5. Nyquist plots for: $a-\beta-\mathrm{Ni}(\mathrm{OH})_{2}, b-\beta-\mathrm{Ni}(\mathrm{OH})_{2} / \mathrm{C}$ composite with different carbon content, $c$-laser irradiated $\beta-\mathrm{Ni}(\mathrm{OH})_{2} / \mathrm{C}$ composite, $d-\beta$ $\mathrm{Ni}(\mathrm{OH})_{2} / \mathrm{C}$ composite subjected to ultrasonic dispersion.

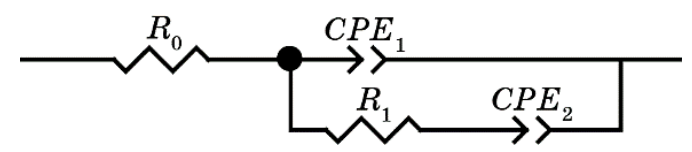

Fig. 6. Equivalent electric circuit for modelling Nyquist plots.

trode/electrolyte boundary, which can be simulated with paralleled constant phase element $C P E_{1}$, which is responsible for the double electric layer capacitance and the ion resistance $R_{1}$ arising when the charge is transferred through the electrode/electrolyte boundary (Fig. 6).

At lower frequencies, Warburg's curve angle of inclination modelled by an element $C P E_{2}$ connected in series, which is responsible for the diffusion processes of ions' translocation along the intercrystallite nickel hydroxide boundaries and carbon particles decreases with modification, which can be explained by the intensive oxidation-reducing processes. The $C P E$ element reflects both an ex- 
ponential parameters' distribution of the electrochemical reaction connected with the overcoming of an energy barrier at the charge and mass transfer and the impedance behaviour caused by the fractal structure of the investigated electrodes surface. In general, the $C P E$ element can be regarded as a manifestation of the properties of fractality in the frequency space.

The semi-circle of the Nyquist plots decreases after carbon addition into the $\beta-\mathrm{Ni}(\mathrm{OH})_{2}$ composites owing to lower charge transfer impedance thanks to the composite's higher conductivity. Thus, the activated carbon reduces the distance for ionic intercalation, and the presence of macro/mesopores formed by nanoplates' shift of the subjected to ultrasonic dispersion nickel hydroxide contributes to the improvement of the electrolyte ions diffusion into the porous structure, which also reduces the value of charge transfer impedance.

We carried out a comparative analysis of the specific energy characteristics of hybrid systems. Subjected to ultrasonic dispersion or laser-irradiated $\beta-\mathrm{Ni}(\mathrm{OH})_{2}$ and $\beta-\mathrm{Ni}(\mathrm{OH})_{2} / \mathrm{C}$ composites acted as a positive electrode. A negative electrode was formed based on nanoporous carbon. $33 \% \mathrm{KOH}$ solution served as electrolyte. As established, the peaks observed on the cyclic voltammograms (Fig. 7) in the intervals of $0.2-0.5 \mathrm{~V}$ and $1-1.3 \mathrm{~V}$ are responsible for oxidation-reduction reactions mechanism.

The plateaus responsible for the course of fast reversible oxidation-reduction reactions or electrochemical adsorption/desorption can be observed on the discharge curves (Fig. 8) at currents of 10 $\mathrm{mA}$ and $20 \mathrm{~mA}$ [6]. The course of cyclic voltammograms confirms it. When the current increases, the values of the specific capacitance of hybrid capacitors drops sharply (Table 2 ).
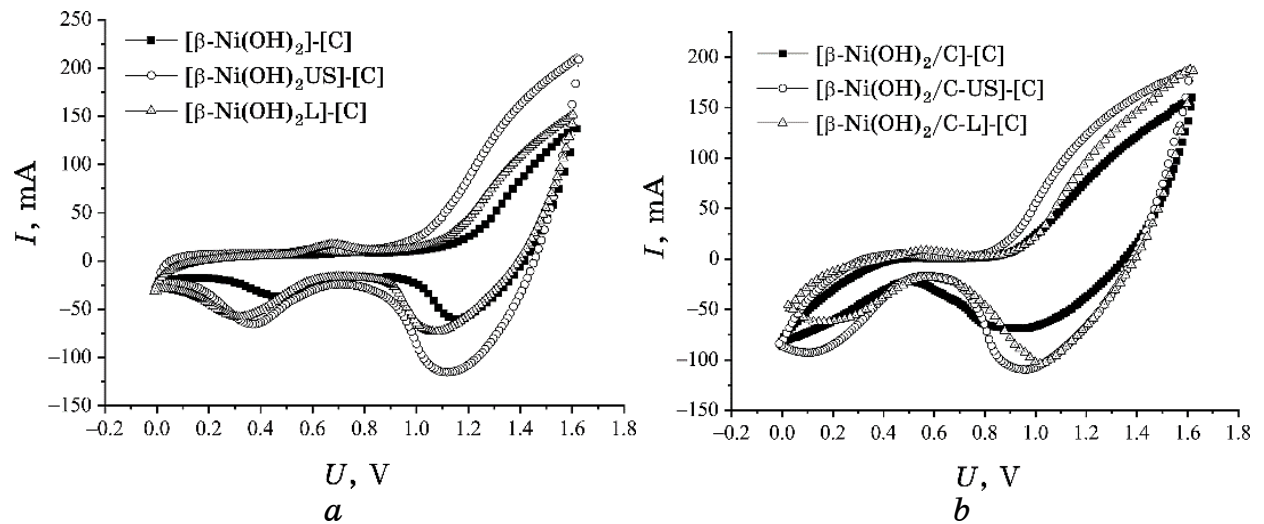

Fig. 7. Cyclic voltammograms of the investigated hybrid systems at scan rate of $10 \mathrm{mV} / \mathrm{sec}$. 

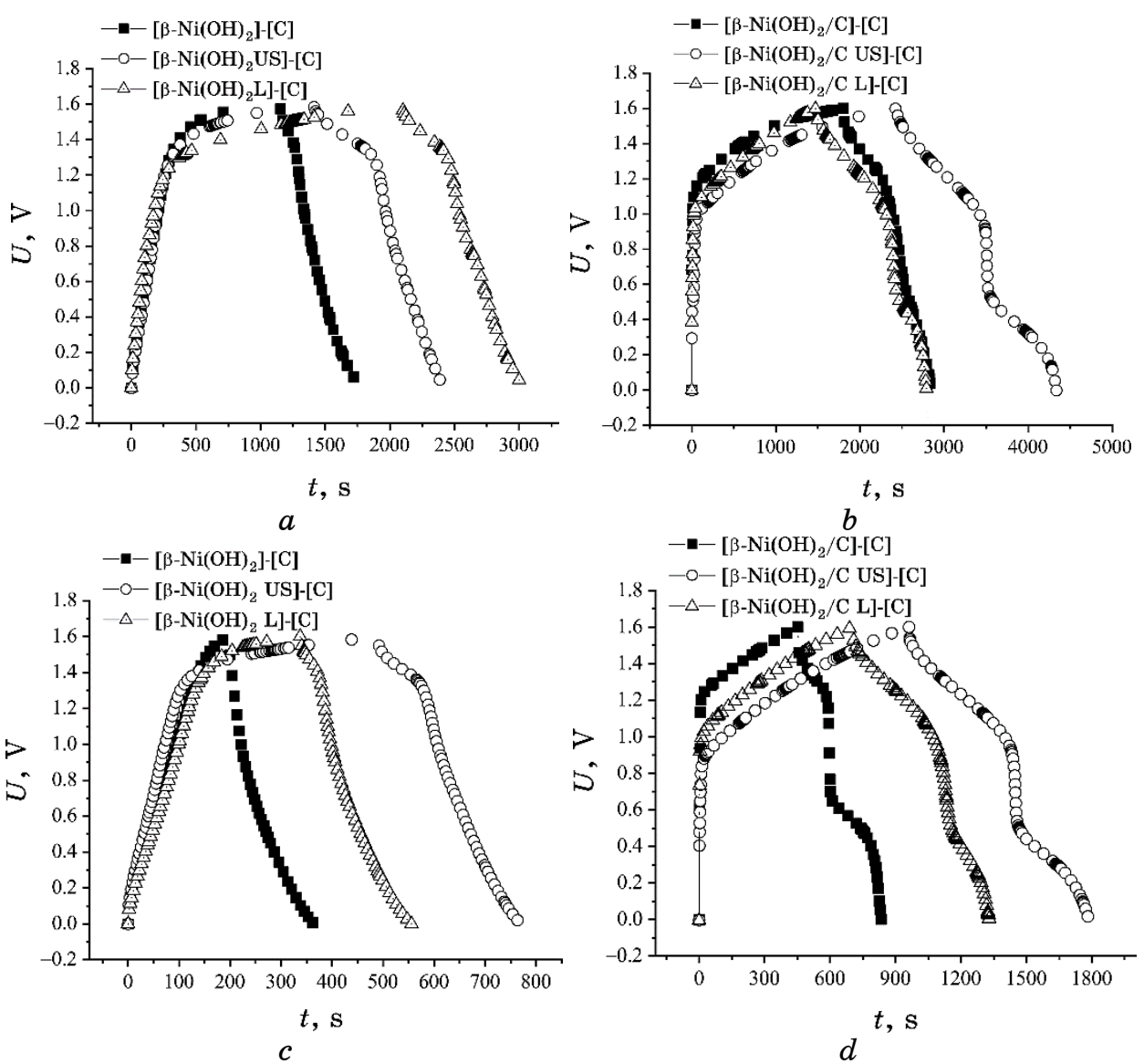

Fig. 8. Galvanostatic charge/discharge hybrid systems curves at current of $10 \mathrm{~mA}(a, b)$ and $20 \mathrm{~mA}(c, d)$.

TABLE 2. Specific capacitive and energy characteristics of the hybrid capacitors, the positive electrode of which is under study.

\begin{tabular}{|c|c|c|c|c|c|}
\hline \multirow{3}{*}{ Cathodic material } & \multirow{2}{*}{\multicolumn{4}{|c|}{$\frac{C_{d}, \mathrm{~F} / \mathrm{g}}{I_{d}, \mathrm{~A}}$}} & \multirow{3}{*}{$E_{s . \max }, \mathrm{W} \cdot \mathrm{h} / \mathrm{kg}$} \\
\hline & & & & & \\
\hline & \multirow{2}{*}{$\begin{array}{c}0.01 \\
104\end{array}$} & \multirow{2}{*}{$\begin{array}{c}0.02 \\
60\end{array}$} & \multirow{2}{*}{$\begin{array}{c}0.05 \\
50\end{array}$} & \multirow{2}{*}{$\begin{array}{l}0.1 \\
42\end{array}$} & \\
\hline$\beta-\mathrm{Ni}(\mathrm{OH})_{2}$ & & & & & 36 \\
\hline$\beta-\mathrm{Ni}(\mathrm{OH})_{2}, \mathrm{US}$ & 257 & 96 & 76 & 33 & 90 \\
\hline$\beta-\mathrm{Ni}(\mathrm{OH})_{2}, \mathrm{~L}$ & 179 & 80 & 46 & 26 & 63 \\
\hline$\beta-\mathrm{Ni}(\mathrm{OH})_{2} / \mathrm{C}$ & 169 & 75 & 53 & 45 & 51 \\
\hline$\beta-\mathrm{Ni}(\mathrm{OH})_{2} / \mathrm{C}, \mathrm{US}$ & 319 & 282 & 213 & 132 & 113 \\
\hline$\beta-\mathrm{Ni}(\mathrm{OH})_{2} / \mathrm{C}, \mathrm{L}$ & 221 & 216 & 137 & 76 & 77 \\
\hline
\end{tabular}


On the one hand, the reason can be carbon material, where the ohmic resistance increases at current growth due to the presence of micropores [7], which limit access to the inner surface of the material. And, on the other hand, it probably can be caused by the irreversibility of oxidation-reduction reactions at high discharge currents.

As can be seen in Table 2 and Fig. 9, the hybrid capacitors one of the electrodes of which is formed based on $\left[\beta-\mathrm{Ni}(\mathrm{OH})_{2} / \mathrm{C}\right.$ US] has the highest specific capacity of $319 \mathrm{~F} / \mathrm{g}$ and specific energy of 113

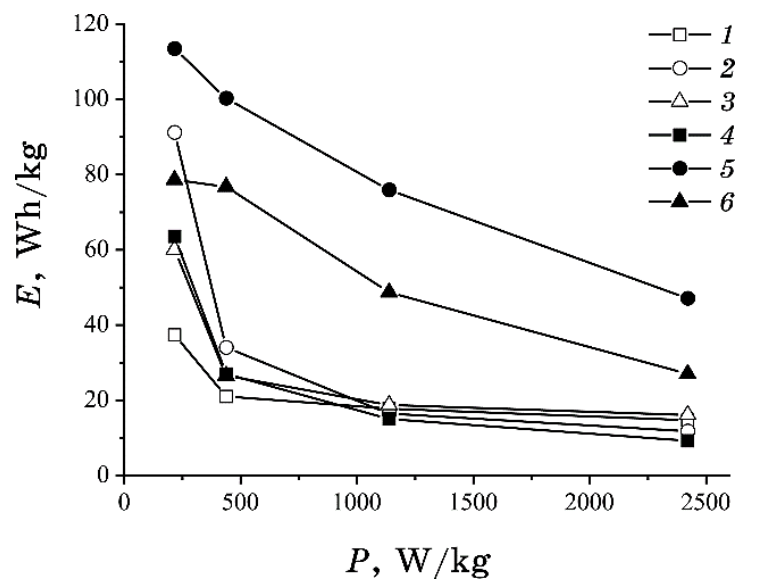

Fig. 9. Dependence of specific energy from specific capacitance for hybrid systems $\left[\beta-\mathrm{Ni}(\mathrm{OH})_{2}\right]-[\mathrm{C}](1),\left[\beta-\mathrm{Ni}(\mathrm{OH})_{2} \mathrm{US}\right]-[\mathrm{C}](2),\left[\beta-\mathrm{Ni}(\mathrm{OH})_{2} \mathrm{~L}\right]-[\mathrm{C}](3)$, $\left[\beta-\mathrm{Ni}(\mathrm{OH})_{2} / \mathrm{C}\right]-[\mathrm{C}](4),\left[\beta-\mathrm{Ni}(\mathrm{OH})_{2} / \mathrm{C} \mathrm{US}\right]-[\mathrm{C}](5),\left[\beta-\mathrm{Ni}(\mathrm{OH})_{2} / \mathrm{C} \mathrm{L}\right]-[\mathrm{C}](6)$.

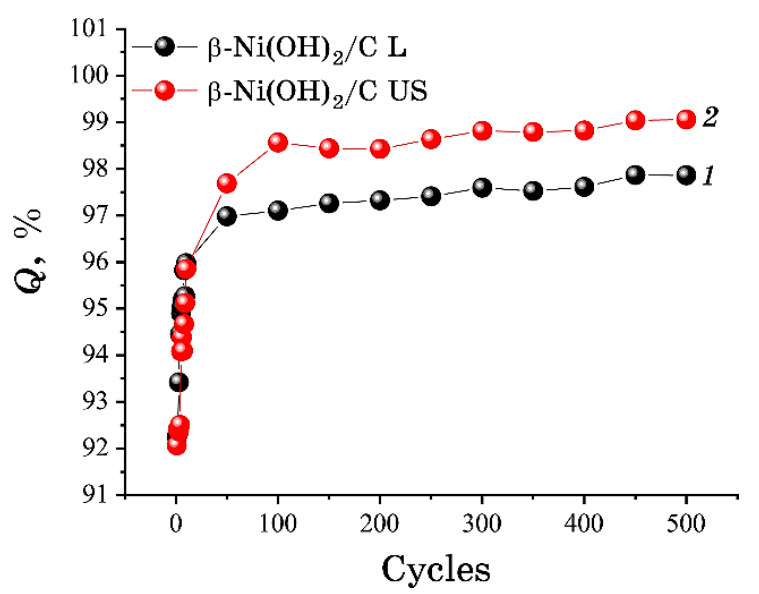

Fig. 10. Dependence of Coulomb's efficiency on hybrid capacitors' cycling with modified $\mathrm{Ni}(\mathrm{OH})_{2} / \mathrm{C}$ composites. 
$\mathrm{W} \cdot \mathrm{h} / \mathrm{kg}$. The accumulation of the charge in such a system may be due to the reaction of cations with the electroactive material followed by the oxidation-reduction reaction. Solid-state oxidationreduction reaction involves electrochemical charge transfer in combination with $\mathrm{H}^{+}$cations intercalation from an electrolyte into the nickel hydroxide laminar structure, where they are held and prevent the phase transition.

Ion intercalation can increase the charge storage in hybrid capacitors without affecting the charge/discharge kinetics.

Hybrid capacitors with subjected to ultrasound and laser irradiation $\mathrm{Ni}(\mathrm{OH})_{2} / \mathrm{C}$ composites as cathodic materials are characterized by the highest specific energy characteristics (Table 2, Fig. 9). The cyclic stability was estimated for 500 cycles at current of $50 \mathrm{~mA}$ (Fig. 10).

It has been established that the Coulomb's efficiency for hybrid capacitors with $\mathrm{Ni}(\mathrm{OH})_{2} / \mathrm{C}$ composites' cathode subjected to laser irradiation reaches $97 \%$ after 50 cycles and practically does not change after 500 cycles. However, in hybrid capacitors with $\mathrm{Ni}(\mathrm{OH})_{2} / \mathrm{C}$ composites' cathode material subjected to ultrasound the efficiency increases gradually reaching 99\% after 100 cycles and does not change after 500 cycles.

\section{CONCLUSIONS}

Modified by ultrasound and laser irradiation $\mathrm{Ni}(\mathrm{OH})_{2} / \mathrm{C}$ composites for the formation of hybrid capacitors are presented for the first time.

It was clarified that the modification by ultrasonic dispersion and laser irradiation leads to the increase in the $\beta-\mathrm{Ni}(\mathrm{OH})_{2} / \mathrm{C}$ nanocomposites' specific capacity (554 and $472 \mathrm{~F} / \mathrm{g}$ at currents of $5 \mathrm{~mA}$ and $10 \mathrm{~mA}$ for a subjected to ultrasound composite) due to the resistance reduction of the active material, contacts and electrolyte and is explained by Faraday and capacitive processes. Their impedance model includes capacitance and resistance arising at the time, when the charge is transferred through the electrode/electrolyte boundary and the element responsible for the diffusion processes and ions' translocation along the intercrystallite nickel hydroxide boundaries and carbon particles, which reduces with the modification. It indicates an increase of the oxidation-reduction processes intensity.

A comparative analysis of the specific energy characteristics of hybrid systems has been carried out, and it has been established that the hybrid systems where one of the electrodes is formed based on $\left[\beta-\mathrm{Ni}(\mathrm{OH})_{2} / \mathrm{C} \mathrm{US}\right]$ have the highest specific capacity of $319 \mathrm{~F} / \mathrm{g}$ and specific energy of $113 \mathrm{~W} \cdot \mathrm{h} / \mathrm{kg}$, respectively. 


\section{REFERENCES}

1. O. M. Hemiy, L. S. Yablon, I. M. Budzulyak, O. V. Morushko, and A. I. Kachmar, Journal of Nano- and Electronic Physics, 8, No. 4: 04074-1 (2016).

2. X. Y. Cao, J. P. Wie, and Y. J. Luo, Int. J. Hydrogen Energy, 25, No. 7: 643 (2000).

3. Y.-M. Wang, D.-D. Zhao, and Y.-Q. Zhao, RSC Advances, 2: 1074 (2012).

4. M. D. Koshel' and V. A. Kotok, Voprosy Khimii i Khimicheskoi Tekhnologii, 6: 187 (2007) (in Russian).

5. I. M. Budzulyak, R. V. Ilnytsky, O. V. Morushko, B. I. Rachii, O. M. Khemii, L. O. Shyyko, and L. S. Yablon, Journal of Nanoand Electronic Physics, 6, No. 4: 04045-1 (2014) (in Ukrainian).

6. S. Min, C. Zhao, G. Chen, and X. Qian, Electrochim. Acta, 115: 155 (2014).

7. S. L. Revo, M. M. Kuzyshyn, and I. M. Budzulyak, Physics and Chemistry of Solid State, 14, No. 1: 173 (2013) (in Ukrainian). 